\author{
Александар Д. СТЕФАНОВИЋ* \\ Université Paris-Sorbonne
}

Оригинални научни рад

Примљен: 08. 11. 2016.

Прихваћен: 10. 02. 2017.

\title{
ДЕКЛИНАЦИЈА ЗБИРНИХ БРОЈЕВА И БРОЈНИХ ПРИДЕВА
}

\begin{abstract}
У раду се осветљава, у дијахронијској и синхронијској перспективи, деклинабилност односно индеклинабилност збирних бројева (двоје, троје, четворо и сл.) и бројних придева (једни, -e, -a; двоји, -e, -a; троји, -e, - $a$ и сл.) у српском језику. Такође се даје дијалектолошки преглед без кога се не може судити о данашњем стању. У раду се ова ситуација упоређује са оном у хрватском стандарду, а посебна пажња посвећена је и становиштима појединих граматичара, који препоручују (врло необичну) употребу бројног придева уместо непроменљивог главног (основног) броја у експлицирању (беспредложног) инструменталног или дативног значења (типа: писао је петорим пријатељииама).

Кључне речи: деклинација, збирни бројеви, бројни придеви, датив, инструментал
\end{abstract}

У школским граматикама и српски и хрватски аутори мало простора посвећују деклинацији збирних бројева и бројних придева. Обично се у граматикама само помињу облици променљивих падежних облика у табелама, а избегавају се опширнија објашњења о њиховој употреби у савременом језику. Још више занемаривања и запостављања грађе о деклинацији збирних бројева и бројних придева показују савремени дијалектолози. Ипак ћемо се за наше истраживање послужити подацима из дијалектолошких монографија које су нам у овом часу доступне, да бисмо што боље осветлили данашње стање. Нашу анализу смо извели на бази језичког материјала који је ексцерпиран како из белетристичких текстова, тако и из есејистичко-публицистичких, укључујући и дневну штампу, али и из говорног језика. Осврнућемо се такође и на неке специфичне облике који су карактеристични за хрватски стандард и указати на препоруку која се односи на употребу бројних придева уместо главних бројева коју предлажу поједини граматичари када је потребно експлицирати дативни и инструментални однос непроменљивих главних

*a.stefano@laposte.net 
бројева, а која је међутим за већину представника како српског тако и хрватског стандардног језика врло необична.

\section{1. Збирни бројеви}

Важно је одмах истаћи да неки граматичари облике двој(e), трој(e), обој(е) и сл. и данас сматрају за облике једнине бројних придева ${ }^{1}$, вероватно идући трагом Вука и Даничића², што се може објаснити историјским фактом $^{3}$, али је неодрживо у стандардном језику.

У нашем раду нисмо, дакле, прихватили ту класификацију, имајући првенствено у виду специфичне синтаксичке карактеристике те две категорија бројева. Дакако, на синтаксичком плану збирни број је партитивна реч и у бројној (партитивној) синтагми он је главна реч која захтева партитивну допуну. Бројни придев је, међутим, конгруентни атрибут именице, а именица је главна реч бројне конструкције (о томе в. Станојчић/Поповић 1997: 95-96).

Деклинирани облици збирних бројева користе се још ређе у модерном језику од деклинираних облика главних (основних) бројева ${ }^{4}$. Штавише, поменути деклинирани облици се појављују са доста варијаната, као што се може видети из следеће табеле:

\begin{tabular}{|c|c|c|c|c|c|}
\hline н/а/(в) & двоје & обоје & обадвоје & mроје & $\begin{array}{c}\text { четворо, чет- } \\
\text { веро итд. }\end{array}$ \\
\hline г & $\begin{array}{c}\text { двог(а)- } \\
\text { двојег(a) }\end{array}$ & $\begin{array}{c}\text { обога- } \\
\text { обојег(a) }\end{array}$ & $\begin{array}{c}\text { обадвога- } \\
\text { обадвојега(а) }\end{array}$ & $\begin{array}{c}\text { трога- } \\
\text { тројега }\end{array}$ & $\begin{array}{c}\text { четворога- } \\
\text { четверога }\end{array}$ \\
\hline д/л & $\begin{array}{c}\text { двома- } \\
\text { двом(е)(у)- }\end{array}$ & $\begin{array}{c}\text { обом(а)(е)(y)- } \\
\text { обојем(у) }\end{array}$ & $\begin{array}{c}\text { обадвома(е)(у)- } \\
\text { обадвојем(у) }\end{array}$ & $\begin{array}{c}\text { трома(е)- } \\
\text { тројем(у) }\end{array}$ & $\begin{array}{c}\text { четворма- } \\
\text { четворома, } \\
\text { четверома(е) }\end{array}$ \\
\hline и & двома & обома & обадвома & трома & $\begin{array}{c}\text { четворма-чет- } \\
\text { верма }\end{array}$ \\
\hline
\end{tabular}

${ }^{1}$ В. нпр. Пецо/Станојчић 1972; Станојчић/Поповић 1997.

${ }^{2}$ В. у: Караџић 1814, 1898 и Даничић 1850, 1872.

${ }^{3}$ Двој, трој, обој итд. (основа и бројним придевима и збирним бројевима), имали су у старијем језику (односно пре Вукових реформи) облике у једнини, дуалу и множини за сва три рода. [Облике у једнини, у неким од њихових значења, још увек помиње покоји савремени хрватски граматичари (в. нпр. Рагуж 1997; Барић et. al. 1999; Силић/Прањковић 2005 - у једном примеру без детаљнијег објашњења, као и Речник српскохрватскога књижевнога језика Матице српске и Матице хрватске из 1967 - у даљем излагању $P M C$; о томе такође в. фн. бр. 18] и коришћени су често на месту где се данас основни бројеви (или неки други бројеви) прописују (о томе такође в. фн. бр. 20). Једино су се облици једнине двоје, троје, обоје итд. одржали у савременом језику и данас се употребљавају као збирни бројеви, а плуралне форме се користе као бројни придеви у врло специфичним лингвистичким ситуацијама. Ипак, неки лингвисти и даље их сматрају као исти тип броја, што је по нашем мишљењу погрешно. Иначе Рјечник хрватскога или српскога језика Југославенске академије знаности и умјетности (у даљем излагању РJAЗУ) нуди за употребу двој, трој, обој итд. обиље примера у старијем језику.

${ }^{4}$ Та констатација важи и за старији језик. У РJA3У можемо наћи много више примера деклинације главних бројева у српском и хрватском језику него деклинације збирних бројева. 
1.1. Код аутора нормативних публикација, у парадигми деклинације сваког од збирних бројева појављују се многобројне недоследности, колебања (чак су неки пут представљани помешани деклинирани облици збирних бројева и бројних придева). Неки граматичари цитирају само облике које сматрају да се користе у садашњем стандардном језику, док други помињу данас ретко употребљаване облике, али који су забележени у старијем језику [то је свакако случај тзв. дугих облика - који су се постепено редуковали: двојега >двог(a); двојему>двом(y) итд., в. нпр. у РЈАЗУ] или у неким штокавским говорима. Као што ће се то видети из примера које смо навели у нашем раду, нотирали смо само (неке) деклиниране облике бројева двоје и обоје; међутим, у поменутој табели наводимо све облике (изузев деклинације бројних придева) које су различити лингвисти поменули у својим радовима, иако смо свесни да нисмо у могућности да потврдимо њихово постојање.

1.2. Према резултатима нашег истраживања (које укључује и интернет), како у писаном тако и у говорном изразу, изгледа да је деклинација збирних бројева већих од 2 (двоје, обоје) данас потпуно нестала (пронашли смо само један пример промене броја троје, в. даље у овом раду); то се противи тврдњама једног броја граматичара који су мишљења да она постоји и за вредности 3 и 4, као и да је чак теоријски могућа и за веће вредности, нарочито када се збирни бројеви не налазе иза предлога (уп.: Станојчић/Поповић 1997: $96)^{5}$.

1.3. У српском стандарду избегавање деклинације збирних бројева се најочигледније констатује када се поменути бројеви налазе иза предлога и када нису у комбинацији с личном заменицом (тада могу бити у комбинацији с квантификованом именицом):

(1) Узеће је са обоје дјеце (...) (В. Драшковић, 158).

Међутим, то избегавање деклинације је такође врло упечатљиво и када број није у комбинацији с предлогом у случају да је конструкција са непромењеним бројем разумљива, као што је то случај у следећем примеру с посесивним генитивом:

(2) (...) вечити медени месец двоје супружника (Д. Стошић, 168) .

1.4. Изгледа да се у свим стиловима (писаном и усменом) најбоље одржао у модерном језику, облик у дативу маркираног броја обоје [обома(е)], и то када је број сам (тј. када није у комбинацији с предлогом или с именицом) јер, као што је то случај с основним бројевима, флексија се не може избећи без промене реченичне структуре. Нпр.:

(3) До скора је та љубав била радост и потреба обома (...) (М. Селимовић, 135).

(4) (...) обома годи (...) (С. Селенић, 22).

(5) Мило обоме, и њему и њој (С. Сремац, 106).

\footnotetext{
5 За старије граматике које укључују хрватски и српски језички материјал, као и за хрватски стандард в. нпр. Маретић 1963: 230; Јонке 1965: 367; Винце/Павешић 1971: 371; Рагуж 1997: 112; Барић et al. 1999: 135.
} 
1.5. Облик у дативу збирног броја двоје (и ређе збирног броја обоје) такође је могућ када је у комбинацији с личном заменицом (у већини случајева када је иза ње) и када иза броја не долази именица:

(6) Али само нама двома (С. Велмар-Јанковић, 249).

1.6. Тај облик у дативу збирних бројева двоје и обоје може се такође забележити у говорном изразу (у комбинацији с предлогом или без њега) као и у колоквијалном, разговорном стилу (нарочито с дијалекатским варијантима као што су двојема, двојма или обојма ${ }^{6}$ ), што нам потврђују следећи примери дискурса:

(7) (...) вама се двојема сваки траг затурио! (В. Драшковић, 60)

(8) Њима двојма покажи прст само, одмах ће се закикотати (3. М. Велимировић, 102).

(9) Ја ћу их гледати и плакати, и нама обојма биће лакше (3. М. Велимировић, 197).

Необичнији је следећи пример употребе дијалекатски обојеног облика у дневној штампи, који ипак доказује да су такви облици присутни у језичком осећању говорника који их вероватно памте из детињства:

(10) Нека им обојма буде Бог у помоћи (Политика, 06/07/2007).

1.7. Када је употребљен без именице али у комбинацији с предлогом који захтева инструментал или локатив, збирни број се понекад деклинира, али су те конструкције обележје пажљивог, негованог језика:

Са личном заменицом:

(11) Све уметничко се зачиње у ґима двома (Ј. Дучић, 241).

(12) Све сам сигурнија да се живот, повремено, баш шегачио са нама двома (...) (С. Велмар-Јанковић, 122)

(13) Шта ће бити с нама трома? Којим трома ? (РТС)

Без личне заменице:

(14) И убрзо потом руковао сам се с обома (...) (Б. Вучичевић, 105)

1.8. Флексија збирног броја (укључујући двоје и обоје), када је део конструкције образоване од броја и именице, врло је ретка, чак и када је потребно експлицирати дативно значење:

(15) Њих двоје не проговорише више ни речи; колико је то могуће двома људима (...) (В. Стојиљковић, 106)

\footnotetext{
${ }^{6}$ Ти се облици, наиме, бележе у неким штокавским говорима (в. нпр. Шимундић 1971: 142; Пижурица 1981: 153; Реметић 1985: 297), али их граматичари и лексиколози не помињу, што није случај неких других облика који се такође само бележе у говорима, али који се третирају као стандардни.

${ }^{7}$ Инструментал, падеж који захтева предлог, присутан је и у питању и у одговору.
} 
Што се тиче претходног примера, врло је интересантно приметити да граматике и речници увек прописују генитив именице иза збирног броја без обзира на то у ком падежу је збирни број.

1.9. Флексија збирних бројева двоје и обоје забележена је такође у генитиву, нарочито када се збирни бројеви, када нису у комбинацији с именицом или личном заменицом, употребљавају, осим за класичну употребу квантификације мешовите групе и за генерално навођење количине:

Мешовита група:

(16) А тужна Смиља нариче час над својим јединцем, час над несуђеном снахом, обоје подједнако спомиње у нарицању свом (...). Несрећни Нинко стао као сињи камен више обога па занемио (М. Глишић, 314).

Генерално навођење количине:

(17) (...) жртва грча или зачепљења срчане артерије, или обога (...) (Б. Вучичевић, 87)

1.10. У поређењу са инструменталом и локативом, изгледа да је флексија збирних бројева много ређа иза предлога који захтева генитив. Навешћемо два примера аутора код којих деклинација збирних бројева постоји у другим падежима, што потврђују горенаведени примери, али не и у генитиву:

(18) (...) неко би од њих двоје устао (...) (В. Стојиљковић, 120).

(19) Нешто од ово двоје (3. М. Велимировић, 323).

Из свега овога можемо, дакле, извући неколико закључака о тенденцијама које се тичу деклинације збирних бројева у савременом српском језику:

Изгледа да једино бројеви двоје и обоје $e^{9}$ познају променљиве облике у модерном језику. То нормативне публикације не потврђују. Наиме, чак и стручњаци који највише инсистирају на реткости деклинације збирних бројева ипак бележе зависне облике (у дативу, локативу, инструменталу и генитиву) броја троје (в. нпр. Ивић et al. 1991; $P M C^{10}$ ).

Што се тиче деклинације та два броја, најчешће се употребљавају облици у дативу обома и двома (неки пут с варијантама), и то када упућују на скуп особа мушког и женског пола. Двома је систематски у комбинацији с личном заменицом док се облик обома може појавити сам. Као што се то дешава с главним бројевима и с збирним бројевима већим од 2 , изворни говорници ће ипак у већини случајева избегавати у реченици дативни однос, односно његово падежно обележје, налазећи, наиме, решење на текстуалном плану.

У негованом језику, та иста два броја могу се деклинирати иза предлога који захтева инструментал или локатив. Изгледа да се увек систематски појављују облици обома и двома (за квантификацију мешовите групе, двома у комбинацији с личном заменицом, а обома може бити сам). Та употреба остаје ипак изузетак, пошто говорници најчешће прибегавају аналитизму.

\footnotetext{
${ }^{8}$ Као што смо већ навели у овом раду, збирни број је партитивна реч и у бројној (партитивној) синтагми, он је главна реч која захтева партитивну допуну.

${ }^{9}$ Истини за вољу нашли смо један пример флексије броја троје (в. пр. 13). Међутим, пошто је та употреба врло маргинална, можемо сматрати ту флексију као скоро потпуно ишчезлу.

${ }^{10}$ Односно у $P M C$ се наводе, такође, зависни облици збирног броја 4, али с напоменом да је та употреба ретка. Што се тиче хрватског стандарда, додајмо да Бабић et. al. 1991, Анић 1994 и Шоње 2000 бележе флексију у дативу/локативу/инструменталу свих збирних бројева, али су мишљења да генитив постоји само за бројеве двоје и троје.
} 
Облици у генитиву двога, обога појављују се у великој већини случајева када генерално упућују на појмове, радње или предмете. Ако никад нису у комбинацији с личним заменицама, често се испред њих налази показна заменица $($ то, ово, оно).

Зависни облици збирних бројева, којима у писаном изразу нарочито прибегавају преводиоци, скоро никада не долазе у комбинацији с именицама.

Ови се закључци тичу како српског тако и хрватског стандардног језика. Супротно ситуацији с основним бројевима, скоро ниједан хрватски граматичар не даје предност њиховој флексији (имајући у виду да је маргинална, а можда чак и потпуно непозната ${ }^{11}$ ) у односу на недеклиниране облике (иако не негирају њихово постојање).

У већини штокавских говора степен променљивости збирних бројева је још слабији него у стандардном језику. Упечатљиво је да дијалектолошке монографије које се баве том проблематиком наводе само врло ретке примере датива, локатива, инструментала, а у знатно мањој мери и генитива бројева двоје, обоје и троје, инсистирајући, међутим, да су аналитичке конструкције увелико доминантне.

\section{2. Бројни придеви}

Бројни придеви имају придевску промену ${ }^{12}$ :

\begin{tabular}{|c|c|c|c|}
\hline & м.p. & ж.p. & c.p. \\
\hline н-(в) & двоји & двоје & двоја \\
\hline г & двојих & двојих & двојих \\
\hline д & двојим(а) & двојим(а) & двојим(а) \\
\hline а & двоје & двоје & двоја \\
\hline и & двојим(а) & двојим(а) & двојим(а) \\
\hline л & двојим(а) & двојим(а) & двојим(а) \\
\hline
\end{tabular}

Остали бројни придеви (једни, -e, - $a$; обоји, -e, - $а$; тројu, -e, - $a$; четво(е)pu, $-e,-a$ итд.) мењају се по истом моделу.

Нормативне публикације углавном помињу (иако не дају прецизнија објашњења - у најбољем случају налазимо неколико примера деклинираних конструкција ${ }^{13}$ ) могућност флексије бројних придева; међутим, констатујемо

${ }^{11}$ Наиме, једино Рагуж (1997), од лингвиста који дају прецизну анализу флексије збирних бројева, у негованом језику даје предност падежним облицима, мада наглашава да су ти облици необични у говорном изразу.

${ }^{12}$ Не наводимо променљиве облике бројних придева у једнини имајући у виду да су скоро потпуно непознати у модерном језику (в. фн. бр. 3 и бр. 18).

${ }^{13}$ Уп.: Ивић et al. 1991: 110, где се указује на чињеницу да су: „углавном [...] изгубили падежну промену". 
да је она скоро нестала, са изузетком флексије броја једни, -е, - $а$ и акузатива других бројева који је у женском и средњем роду идентичан номинативу (примери илуструју ситуацију у српском и хрватском стандарду):

(20) Када су га предвече премештали са једних огуљених леђа на друга (...) (Б. Драгојевић, 16).

(21) Носим троје ${ }^{14}$ на срдашцу јаде (И. Мажуранић, 48).

Током наших истраживања скоро да нисмо нашли ниједан други тип флексије [сем специфичног случаја са именицом врата иза предлога $c(a)$, в. даље], пошто аутори увек нађу такво решење на текстуалном плану које им омогућава да избегну деклинацију бројних придева у другачијим падежима од оних које смо горе навели. Тако је аналитичка деклинација врло фреквентна:

(22) (...) прође поред двоја врата (Д. Рисимовић, 274).

Примери деклинације иза предлога су врло ретки: нашли смо наиме само синтагме с именицом врата иза бројног придева и предлога $c(a)$, и то (што је врло занимљива појава) да би се означио број врата на возилу. Исти закључци вреде и за говорни језик; наиме, нико неће данас рећи: „од двојих врата” или „тројим колима” (примери преузети од Ивић et al. 1991) и сваки говорник ће их природно заменити недеклинираним конструкцијама „од двоја врата”, „са троја кола”. ${ }^{15}$ Исто тако забележили смо само аналитичке формулације за квантификацију врата неког возила: c(a) mpoje, пето(e)po врата, али је овде реч о употреби облика збирног броја.

Када је реч о хрватском стандарду, употреба тог типа деклинираних синтагми иначе је много ређа од употребе аналитичких конструкција: $c(a)$ mpoje, nето(е)ро врата, што су облици конструкције са збирним бројем. ${ }^{16}$

Можемо навести неколико релевантних примера:

(23) Упуте за упорабу хладњака Кончар Ардо: модели са двојим вратима. (Техничко упутство)

(24) (...) јапански ће произвођач представити Мазду 2 с тројим вратима (...) (Јутарњи лист, 24/01/2008, „Мазда 2 с тројим вратима у Женеви”)

(25) Прве службене фотографије приказују основни модел с петорим вратима. (Јутарњи лист, 24/01/2008)

(26),,(..) хоћу онај са шесторим вратима.” (С. Бабић, 163)

Вредно је нотирати да поједини граматичари ${ }^{17}$ препоручују да се уместо непроменљивих основних бројева од nет па надаље употребе деклинирани облици бројних придева у случају експлицирања (беспредложног) дативног или (стандардно) инструменталног односа (потребно је, међутим, да кванти-

\footnotetext{
${ }^{14}$ Употреба мушког рода бројних придева је скоро потпуно ишчезла у модерном језику.

${ }^{15}$ Деклинација бројних придева (изузев једни, -e, - $a$ ) такође је врло ретка у штокавским говорима иако се трагови понекад могу наћи и скоро увек у дативу-локативу-инструменталу за вредности 2, 3, 4 .

${ }^{16}$ Старији хрватски граматичари наводе да се „бројни [се] придјеви претежно употребљавају у номинативу, акузативу и вокативу плурала, али и у другим падежима” (Павешић/Винце 1971: 370).

${ }^{17}$ В. нпр. Маретић 1963: 223; Барић et al. 1999: 135.
} 
фикована именица буде женског или средњег рода или да означава мешовиту групу или предмете или животиње мушког рода). ${ }^{18}$

Тако у свом Језичком савјетнику са граматиком, загребачки лингвисти Славко Павешић и Златко Винце препоручују следеће облике: шестерим женама, шестерим снахама, седмерим селима, а Јонке (1965: 390) пише: „Ипак у књижевном се језику појављује приједлог с или са и за изрицање средства кад је пред нама несклоњив израз. Сасвим је добро рећи и написати: 'Разрезао сам с осам ножева' јер се број осам не деклинира, али кад мјесто тог броја употријебим деклинабилни број осмеро ${ }^{19}$, нема мјеста приједлогу, па је правилно: 'Разрезао сам осмерим ножевима'".

Рагуж (1997) упозорава, међутим, на претерану употребу бројних придева када је потребно деклинирати (у дативу) „пет коња”, „седам жена” итд. Рагуж наводи да су примери деклинације које нуде неке граматике типа „петерим коњима” или „седмерим женама” у принципу прихватљиви и коректни, али само као деклинирани облици синтагми „петери коњи” и „седмере жене”. Што се тиче деклинације (у дативу) синтагми типа „пет коња”, „седам жена" итд. (тј. у случају индеклинабилности основних бројева), Рагуж предлаже реконструкцију реченице: „Било је пет коња, седам жена (итд.) којима...".

Овакво решење препоручивали су поједини и српски и хрватски лингвисти (нпр. Т. Маретић, Љ. Јонке. М. С. Лалевић). Према Љубомиру Поповићу, „начини да се истовремено постигне променљивост и броја и квантификоване именице представља употреба бројног придева за квантификацију свих именица, а не само оних које својом множином означавају функционалне целине; уп. Марија је то рекла петорим другарицама.” „Главна мана овог решења није извесна могућност да дође до забуне у вези са бројним значењем (уп. различито значење израза пет рукавица: петоре рукавице = пет пари рукавица), него чињеница да ово решење није ухватило корена у језич-

\footnotetext{
${ }^{18}$ Једино Силић/Прањковић (2005: 144) говоре о могућој употреби бројних придева, у беспредложним синтагмама, када је потребно деклинирати непроменљиве бројеве, не узимајући у обзир граматички или природни род референата означених квантификованом именицом. Нуде следеће примере: „Тим је петнаесторим сиромашним грађанима потребна помоћ”; „Својој је седморој дјеци осигурао смјештај у неколико приватних станова”; „Тим би се деветорим спорташицама сватко могао поносити.” Ти нам закључци делују врло необично (нисмо нашли скоро ниједан пример таквих бројних синтагми, осим у неким врло ретким приликама на интернету), нарочито формулације петнаесторим грађанима (дакако, могућа употреба збирних бројева или евентуално бројних именица на -ица који су и једни и други променљиви - барем теоријски што се тиче збирних бројева, в. горе) и седморој дјеци (непостојећа употреба бројних придева у једнини у модерном језику). Додајмо и то да неки ретки граматичари или лексиколози [в. нпр. Рагуж 1997; Барић et. al. 1999; Силић/Прањковић 2005 (у наведеном примеру, без даљег објашњења) као и у $P M C]$ ипак помињу сингуларни облик бројних придева који би се наводно употребио у врло специфичним лингвистичким ситуацијама. Ради се о реткој, архаичној употреби, стилистички маркираној као врло књижевној и која се по нашем мишљењу никад не појављује у модерном језику. Цитирају је тако врло стари граматичари као нпр. Мажуранић 1869; у PJA3У, изузев дијалекатских облика или примера преузетих из усмене књижевности, бележи се само до 19. века. В. такође фн. бр. 3 о пореклу те употребе.

${ }^{19}$ Јонке вероватно сматра да су збирни бројеви облици једнине бројних придева (класификацију коју нисмо прихватили, в. горе). Подсетимо такође да је бројни придев у мушком роду за вредност 8 осмери.
} 
кој пракси, и то не само зато што нарушава принципе дистрибуције бројева у српскохрватском језику, него вероватно још више зато што се бројни придеви све мање и све несигурније употребљавају чак и тамо где би им по књижевној норми било место. Но иако представља само књишко решење, употреба бројних придева има предност што системски решава скоро све случајеве где експлицирање датива представља проблем и што не оптерећује структуру текста, а то је чињеница која је од битног значаја, на пример, за преводиоце” (Поповић 1981-1982: 607).

Као што смо то већ претходно навели, нисмо нашли готово ниједан пример употребе деклинираних бројних придева уместо непроменљивих основних бројева, осим неких врло ретких потврда на интернету. Према коментарима изворних говорника та употреба бројних придева никако не одговара њиховом језичком осећању ${ }^{20}$. То гледиште код неких граматичара по којем се бројни придеви могу употребити уместо главних бројева може се вероватно објаснити историјским фактом. Наиме, раније, у старијем језику деклинирани облици бројног придева обоји у мушком роду су понекад коришћени уместо, тада слабо познатих, зависних облика главног броја оба у средњем и мушком роду (а неки пут и женског рода обе) ${ }^{21}$. Та употреба се не бележи у модерном језику, пошто је деклинација мушког/средњег рода оба(два) и женског рода обе (обадве) најчешће замењена дескриптивним еквивалентом ${ }^{22}$ : и један (-a) (-o) и други (-a) (-o) (или алтернативним формама: $u+$ именицца/ придев ... и + именица/придев).

И да закључимо: спроведена анализа је показала да је деклинација збирних бројева и бројних придева (осим броја једни, -e, - $a$ ) све ређа у модерном језику. Изгледа да једино бројеви двоје и обоје познају променљиве облике и то у неким врло специфичним ситуацијама. Такође смо показили да се употреба бројних придева уместо главних бројева коју предлажу поједини граматичари када је потребно експлицирати дативни и инструментални однос није укоренила у језику вероватно јер говорници или избегавају у реченици дативни однос, односно његово падежно обележје, налазећи решење на текстуалном плану, или прибегавају (не потпуно стандардном) губљењу формалне разлике између социјативног и инструменталног значења употребом социјативног предлога $c(a)$.

\footnotetext{
${ }^{20}$ Слична ситуација је и у хрватском стандарду: у Хрватској граматици наводи се један једини пример бројног придева већег од 4 у дативу преузет из загребачког дневног листа Вјесник (то је уосталом једини пример који није конструисан као што је то случај у осталим граматикама): „Петорим станарима предани су кључеви новог стана” (Барић et. al. 1997: 566). Такође се наводи један врло чудан пример: „Говорити о четверим представама”, где се ради о архаичној употреби бројног придева уместо стандардног основног броја (четирима) (Барић et. al. 1997: 221), в. о томе фн. бр. 3.

${ }^{21}$ О томе опширније в. Милановић 1952.

${ }^{22}$ То наравно важи и за кореспонденте: обоје, обадвоје, обоји(а)(e), обадвоји(а)(e).
} 


\section{ИЗВОРИ}

\section{а) књижевноуметничка дела:}

C. Бабић - Stjepan Babić, Hrvatski politički vicevi, Zagreb: PIP, 1995.

3. М. Велимировић - Зорка. М. Велимировић, Медвед и друге драме [превод с руског, наслов оригинала: Медведь (прва драма) (Чехов)], Београд: Народна просвета, 1939.

С. Велмар-Јанковић - Светлана Велмар-Јанковић, Лагум, Београд: Стубови културе, 2001.

Б. Вучичевић - Branko Vučičević, Lolita, [превод с енглеског (V. Nabokov)], Beograd: Narodna knjiga, 1984.

Б. Драгојевић - Бранислав Драгојевић, Башта на Исланду, Крагујевац: Светлост, 1985.

В. Драшковић - Вук Драшковић, Нож, Београд: Српска реч, 1998.

Ј. Дучић - Јован Дучић, Благо цара Радована, Београд: Колосеум, 1997.

М. Глишић - Милован Глишић, Целокупна дела (књига прва), Библиотека српских писаца - Београд: Народна просвета, 1928.

И. Мажуранић - Ivan Mažuranić, Smrt Smail-Age Čengića, Zagreb: Zora, 1965.

Д. Рисимовић - Dragoslava Risimović, Jesen u Pekingu [превод с француског; наслов оригинала: L’Automne à Pékin (B. Vian)], Beograd: Nolit, 1983.

C. Селенић - Slobodan Selenić, Očevi i oci, Beograd: Prosveta - Dereta, 1996.

М. Селимовић - Меша Селимовић, Круг, Београд: Блиц, 2008.

С. Сремац - Стеван Сремац, Поп Ћира и non Спира, Београд: JPJ, 1998.

В. Стојиљковић - Vlada Stojiljković, 1984 [превод с енглеског; наслов оригинала: Nineteen eighty-four (G. Orwell)], Beograd: BIGZ - Zagreb: August Cesarec, 1984.

Д. Стошић - Dobrila Stošić, Tereza Raken [превод с француског; наслов оригинала: Thérèse Raquin (E. Zola)], Beograd: Branko Đonović, 1964.

A. Шеноа - August Šenoa, Čuvaj se senjske ruke, Zagreb: Mladost, 1981.

\section{б) новине:}

Вјесник - Vjesnik, дневне новине, Zagreb Јутарњи лист - Jutarnji list, дневне новине, Zagreb

Политика - Политика, дневне новине, Београд

в) телевизијске станицее:

РТС - Радио-телевизија Србије 


\section{ЛИТЕРАТУРА}

Анић² 1994: V. Anić, Rječnik hrvatskoga jezika, Zagreb: Novi Liber.

Бабић et al. 1991: S. Babić, D. Brozović, M. Moguš et al., Povijesni pregled, glasovi i oblici hrvatskoga književnoga jezika, Zagreb: Hrvatska akademija znanosti i umjetnosti - Globus.

Барић et al. ${ }^{4}$ 1997: E. Barić, M. Lončarić, D. Malić et al., Hrvatska gramatika, Zagreb: Školska knjiga.

Барић et al. 1999: E. Barić, L. Hudaček, N. Koharović et al., Hrvatski jezični savjetnik, Zagreb: Školske novine.

Даничић 1850: Ђ. Даничић, Мала српска граматика, Беч: Штампарија јерменског манастира.

Даничић 1872: Ђ. Даничић, Облици српскога или хрватскога језика, Загреб: Штампарија Драгутина Албрехта.

Ивић et al. 1991: П. Ивић, И. Клајн, М. Пешикан, Б. Брборић, Српски језички приручник, Београд: Београдска књига.

Јонке $\mathbf{2}^{2}$ 1965: Lj. Jonke, Književni jezik u teoriji i praksi, Zagreb: Znanje.

Караџић 1814: В. Караџић, Писменица сербскога їезика, Беч: Печатньа Іоана Шнирера.

Караџић $^{3}$ 1898: В. Караџић, Српски рјечник, треће (државно) издање, Београд.

Маретић ${ }^{3}$ 1963: T. Maretić, Gramatika hrvatskoga ili srpskoga književnog jezi$k a$, Zagreb: Matica hrvatska.

Мажуранић ${ }^{4}$ 1869: A. Mažuranić, Slovnica hervatska, Zagreb.

Милановић 1952: Б. Милановић, „О употреби бројног придева обоји”, Наш језик, IV/1-2, 38-44.

Павешић/Винце 1971: S. Pavešić, Z. Vince, Jezički savjetnik s gramatikom, Zagreb: Matica hrvatska.

Пецо/Станојчић 1972: А. Peco, Ž. Stanojčić, Srpskohrvatski jezik: Enciklopedijski leksikon, Beograd: Interpres.

Пижурица 1981: М. Пижурица, Говор околине Колашина, Титоград: Црногорска академија наука и умјетности, посебна издања.

Поповић 1981-1982: Љ. Поповић, „Неусаглашеност форме и функције непроменљивих бројева у српскохрватском језику: проблем датив”, Македонски јазик, XXXII-XXXIII, Скопје, 603-609.

Рагуж 1997: D. Raguž, Praktična hrvatska gramatika, Zagreb: Medecinska naklada.

Реметић 1985: С. Реметић, Говори цุентралне Шумадије, Београд, Српски дијалектолошки зборник, XXXI, XIX + 1-555.

Речник српскохрватскога књижевног језика, I-VI, Матица српска (Матица хрватска), Нови Сад (Загреб), 1967-1976.

Рјечник хрватскога или српскога језика-Rječnik hrvatskoga ili srpskoga jezika, Jugoslavenska akademija znanosti i umjetnosti, Zagreb, 1-23, 1880-1976.

Силић/Прањковић 2005: J. Silić, I. Pranjković, Gramatika hrvatskoga jezika, Zagreb: Školska knjiga. 
Станојчић/Поповић ${ }^{5}$ 1997: Ж. Станојчић, Љ. Поповић, Граматика српскога језика, Београд: Завод за уџбенике и наставна средства.

Шимундић 1971: M. Šimundić, Govor Imotske krajine i Bekije, Sarajevo: Djela Akademije Nauka BiH, XI, knj. XXVI.

Шоње 2000: J. Šonje (glav. urednik), Rječnik hrvatskoga jezika, Zagreb: Leksikografski zavod „Miroslav Krleža” i Školska knjiga.

Aleksandar Stefanovic

\section{LA DÉCLINAISON DES NUMÉRAUX COLLECTIFS ET DES ADJECTIFS NUMÉRAUX}

\section{Résumé}

L'article a pour ambition d'éclairer par une approche diachronique et synchronique la déclinabilité ou plus précisemment l'indéclinabilité des numéraux collectifs (dvoje, troje, četvoro, etc.) et des adjectifs numéraux (jedni, $-e,-a ; d v o j i,-e,-a$; troji, $-e,-a$; četvori, $-e$, $-a$ etc.). L'auteur propose également une approche dialectale sans laquelle une analyse de la situation linguistique actuelle ne serait envisageable. Une attention toute particulière est portée aux avis de certains grammairiens qui proposent l'emploi (fort étrange) des adjectifs numéraux à la place des numéraux cardinaux indéniclables lorsqu'il s'agit d'expliciter l'instrumental standard ou le datif (du type pisao je petorim prijateljicama)

Mots clés : déclinaison, numéraux collectifs, adjectifs numéraux, datif, instrumental. 